\title{
F2RL3 wt Allele
}

National Cancer Institute

\section{Source}

National Cancer Institute. F2RL3 wt Allele. NCI Thesaurus. Code C102543.

Human F2RL3 wild-type allele is located in the vicinity of $19 p 12$ and is approximately $3 \mathrm{~kb}$ in length. This allele, which encodes proteinase-activated receptor 4 protein, is involved in the modulation of both platelet activation and receptor signaling. 